\title{
Problems of Old-Age Pension Reform in China's Colleges and Universities
}

\author{
Yuming Lin ${ }^{1,2}$, Jingwen Tan ${ }^{1}$ \\ ${ }^{1}$ School of Public Administration and Emergency Management, Jinan University, Guangzhou, China \\ ${ }^{2}$ Center for Social Security Studies of Wuhan University, Wuhan, China \\ Email:602045221@qq.com
}

How to cite this paper: Lin, Y. M., \& Tan, J. W. (2018). Problems of Old-Age Pension Reform in China's Colleges and Universities. Creative Education, 9, 2843-2855. https://doi.org/10.4236/ce.2018.916213

Received: November 23, 2018 Accepted: December 18, 2018

Published: December 21, 2018

Copyright (c) 2018 by authors and Scientific Research Publishing Inc. This work is licensed under the Creative Commons Attribution International License (CC BY 4.0).

http://creativecommons.org/licenses/by/4.0/

\begin{abstract}
In China, school and hospital staff account for approximately $70 \%$ of the total staff in public institutions. In the second half of 2014, the central government embarked on the old-age pension reform of public institutions that would be introduced in 2015. The pension reform of colleges and universities is considered the bellwether of this reform. Nowadays, the old-age pension reform of administrative units has already started, but the reform of colleges and universities has not been implemented yet. This article attempts to explain the slow progress in pension reform and propose corresponding solutions. A breakthrough in this regard requires great political wisdom and sufficient financial support. Only in this way can the entire society address social conflicts, solve practical problems, and achieve ideal reform goals.
\end{abstract}

\section{Keywords}

Pension Benefits, Occupational Pension, System Reform

\section{Introduction}

The dual system of pension refers to the different retirement pension systems for personnel due to the distinct nature of employment. This dual-track system is a special product during the transition period between central planning and market economy for the purpose of enhancing social justice and promoting social mobility. After having been criticized for a long time, the system has finally been changed in recent years. In response to a request from the central government, the Standing Committee of the State Council and the Standing Committee of the Political Bureau of the Central Committee reviewed and approved the reform plan for the old-age pension system of public institutions on December 23, 2014. 
In accordance with the reform idea of "one goal, five aspects", the plan proposes to establish an old-age pension system, in which urban workers should pay for their old-age pension like what urban employees and urban residents do. The reform would be carried out from October 1, 2014. In response to a request from the central government, the Standing Committee of the State Council and the Standing Committee of the Political Bureau of the Central Committee reviewed and approved the reform plan for the old-age pension system of public institutions on December 23, 2014.

Thus far, public institutions in China have developed rapidly. According to the Communist Party of China (CPC) News Network, 1.26 million public institutions in China currently have more than 30 million formal employees. However, the definition of public institution is unclear. The nature, size, access conditions, amount of funds, function, number of personnel, behavior supervision, and other aspects of management of public sectors are quite chaotic. For instance, some public institutions provide the same services as the government, whereas other public institutions seem to only manage civil servants. Distinguishing whether an organization is administrative, quasi-administrative, profit-making, or non-profit-making is difficult. Moreover, the funds of public institutions are categorized into three types: Full financial support, partial support, and self-financing. The above situations threaten the financial system and exert crowding out effect on the service-oriented government. Therefore, a few foreign scholars regard China's ambiguous public institutions as "government agencies". According to the current classification standards, colleges and universities are public welfare organizations, which belong to public institutions. However, some colleges and universities have multiple identities such as school-run enterprises, profit-making companies, and development-oriented research units. Many school leaders or teachers have leadership positions in school-run enterprises or hold other technical part-time jobs. Therefore, colleges and universities, as the second class of public welfare organizations, also possess certain characteristics of government agencies.

Regarding the reform of the old-age pension system of colleges and universities, the issue of funds is inevitable. The funds of colleges and universities mainly come from the financial allocation of the central government and local governments. In the late 1990s, with the establishment and development of the socialist market economy, the investment system of higher education has undergone a series of reforms, and the investment subjects have been completely changed. Now, social capitalists are allowed to invest in higher education, which used to be impossible. A multi-school-running system consisting of "financial grants, education taxation, tuition fees, social donations, student aid funds, and research funding" has been formed. The sources of funds for colleges and universities students in China vary dramatically. Relevant statistics indicate that state appropriation is $58.7 \%$, self-raised funds account for $21.1 \%$, and social donations account for $20.2 \%$. Higher education institutions in China include technical colleges, independently established colleges and universities, and so on. The finan- 
cial allocations for 211 national and 985 project universities are relatively adequate. In 2014, the government revisited the old-age pension reform of administrative institutions and prioritized it. The signal from the government demonstrated that the reform mainly focuses on transformation mechanism not benefit reduction. In addition, the government has a policy arrangement for the retirees of public institutions, such as the mandatory establishment of occupational pension as supplementary pension insurance. However, after the introduction of positive policies, the reform continues to face seven problems.

\section{Problems and Solutions}

First, the origin of the social pooling fund of basic old-age pension is vague.

The central government requested that public institutions be formally involved in the pension insurance reform from October 1, 2014. The method of reforming the old-age pension of public institutions is basically the same as the reform method for enterprises, in which units and individuals both pay the basic old-age pension contributions. The proportion that the units pay for the basic old-age pension is $20 \%$ of the total wage of the unit, forming the pooled social funds (hereinafter referred to as unit contributions). The proportion that individuals pay for basic old-age pension is $8 \%$ of their own wages, which are withheld by the unit (hereinafter referred to as individual contributions), thus forming the personal account of the basic old-age pension. By the end of 2015, most provinces and cities across China had introduced provincial-level plans for the reform, but the fees of administrative units in Guangdong Province were paid temporarily in 2017. Except for a few regions, the reform of old-age pension in colleges and universities in most provinces and cities in China has not made any substantial progress.

Colleges and universities are part of public welfare organizations. The No. 2 document issued by the state (2015) does not specify whether the unit contribution for the basic old-age pension is paid by the government or by the universities, causing a gray area in the reform. The document also proposed that the staff of public institutions should fulfill their payment obligations in accordance with state regulations, enjoy the corresponding pension insurance benefits, and finally form a fundraising and distribution mechanism of old-age pensions that share responsibility and coordinate mutual aid. To this end, the staff must pay $8 \%$ of personal wages to participate in the reform of pension insurance and then focus on whether they will make up for this part of the payment by raising wages. Younger faculty with lower income particularly looks forward to this change. In 2015 , colleges and universities began to raise wages, which is a prelude to the reform. Raising salary can be adopted to solve the problem, but if the government does not subsidize colleges and universities, promote pension reform will be difficult for many colleges and universities. Without change, education units in the future may be unable to afford the payment in the middle and later stages of the reform (Wang et al., 2018; Miyazaki \& Koichi, 2014). Moreover, it is urgent to merge all social pensions into one scheme. The urgency is because the 
gap in pension funding is so large and those in public institutions are the clear winners, and the whole pension scheme is not so equitable (Zhu \& Walker, 2018; Wang et al., 2014).

Second, guaranteeing that the pensions will not be cut after the reform is challenging.

A gradual and prudent approach has been taken in the process of old-age pension reform. For those who have retired before the reform, their benefits remain unchanged and they will participate in the adjustment in the future. For those who started working after the reform, a new mechanism is established to achieve a reasonable connection of individual treatment. For those who joined the workforce before the reform and then retired after the reform, the government will implement the transitional measures to maintain the level of treatment. In fact, the pension treatment of college and university staff across China vastly differ. For example, retirement benefits for professors in Guangzhou are at least 2000 yuan higher than those in Shanghai, not to mention the gap between various universities and provinces (Zhao \& Yang, 2017). Two policy options can possibly address the issue of pension benefits. First, using transitional pension to bridge the gap; second, using the pooled social trust fund to fill in the gap left by the incomplete transformation. The pay gap is a sensitive issue, and the government may not infringe upon the interests of post-reform retirees. The truth is no pension funds accumulate at the beginning of the reform of the old-age pension for public institutions, so relying on transitional pension to solve these problems is unrealistic.

Third, the source of occupational pension funds bewilders indebted colleges and universities.

Occupational annuities are a more sensitive issue than basic old-age pension, and it can be divided into two categories. One unit is financially allocated, whereas the other unit is self-supporting or receives subsidies. The proportion of occupational annuities in units with good benefits is high, but that in units with poor returns is correspondingly low. Individual contributions of the latter are more than those of the former, fully reflecting the incentive mechanism and the principle of social equity.

Unlike the enterprise annuity system, which is encouraged, the occupational pension system of the old-age pension reform of government institutions is enforced. As a form of supplementary old-age pension system, occupational annuity contributions are paid by the institutions and individuals together. The proportion of occupational annuity contributions paid by institutions such as colleges and universities is $8 \%$ of the total salary of the unit, and the proportion of individual contributions is $4 \%$ of their wages, which is deducted by the unit. The contribution base of occupational annuity is consistent with the basic old-age pension contribution base of the staff of institutions. Given the varying economic conditions of different universities, if the institutional annuity system is not enforced and does not receive financial support, occupational annuity may eventually evolve into a "club of the rich" in select colleges and universities. 
Universities across China face imbalanced economic development due to their local economic situation. According to Hoyle, for the unit with financial allocations (administrative unit), payment is recorded by means of bookkeeping, and interest is calculated according to the saving rate published by the state. When a staff member retires, the balance in his individual occupational annuity account shall be allocated by the financial department. For units that are not fully financed (colleges and universities belong to such units), unit contributions are recorded on the basis of actual accumulation. The occupational annuity funds formed by accumulation of real accounts have been absorbed under marketing operation, and interest is calculated according to actual income. Consequently, the pension of colleges and universities consists of three parts: unit contributions, individual contributions plus earnings, and other income from occupational annuity investment operations. The income of colleges and universities is a crucial source of unit payment. For colleges and universities with poor economic conditions, this is undoubtedly a heavy burden. The Treasury does not indicate whether it will subsidize occupational pension in universities. If colleges and universities have to sort themselves out, then the financial situation of many local colleges and universities that are already in debt may deteriorate.

Given the tremendous cost of building a new campus, the welfare of some universities has been seriously affected. "The Ministry of Finance's Opinions on Reducing the Debt Burden of Local Colleges and Universities" pointed out that in recent years, a number of colleges and universities have continuously been exposed to debt risks upon reaching the peak of repayment of loans. This circumstance seriously restricts their sustained development. According to reports, 1164 local universities in China were in debt of roughly 263.498 billion yuan by 2010. Colleges and universities in Hubei Province were burdened with a debt of more than 10 billion yuan. Jilin University, which was formed by merging six universities, had paid off 3 billion yuan worth of debt through land sales. Since 2005, Jilin University has entered the peak period of interest payment, and the interest that needed to be paid annually is as high as 150 to 170 million yuan. Being unable to make ends meet is becoming severe in China, with the blind expansion of college construction and the lack of government investment leading to a more dreadful financial situation in local colleges and universities. If the government fails to discharge the debt, eliminate debt risks, and establish a long-term mechanism to control financial risks in colleges and universities, then the development of occupational annuity of colleges and universities will be severely limited and even affect the entire reform.

Fourth, the reduction of pension may be compensated through occupational annuity.

The old-age insurance system of government organs and institutions should be included in the scope of reform in accordance with the principle of unionization. The salary structure of administrative institutions is classically more complicated than that of enterprises. Moreover, the perks before the reform of subsidies used to occupy a considerable proportion, which will make the calculation 
of old-age pension contribution base difficult to determine. With the development of the eight-point guidelines issued by the CPC, many perks of colleges and universities have been abolished, income is mainly based on performance wages, and earnings are more transparent than before. However, in the part of living subsidy, discrepancy among various universities in different regions is significant. To determine the payment standard, further research is required. Converging the contribution base of public institution with the company one will be conducive to the integration of old-age pension, but it will take time.

The replacement rate of college pensions is approximately $90 \%$, and that of enterprises is roughly $60 \%$. If the calculation method of the basic pension of enterprise employees is implemented completely, then the pension replacement rate of colleges and universities' retirees will be greatly reduced. The difference in the level of benefits compared with pre-reform retirees is too large, and it will lead to widespread complaints from retirees after the reform. Without reducing the replacement rate, the merger will be meaningless. Thus, making up for the reduction of pension through occupational annuity is necessary. Specifically, the current worldwide development trend of old-age pension for public institutions is to establish a three-pillar insurance system, namely, national basic pension, supplementary pension insurance, and employee (staff) personal savings pension insurance. Among them, the replacement rate of basic old-age pension in developed countries is lower, whereas the replacement rate of the second and third pillars are high. Prof. Li Shi, Executive Dean of the China Institute of Income Distribution at Beijing Normal University, believes that in the next 8 to 10 years, the pension replacement rate gap between public institutions and enterprises will gradually narrow.

Fifth, ensuring the benefits of "middle people" is difficult.

Within China's pension system of colleges and universities, staffs are classified into three types: "middle people," "new people," and "old people." "Middle people" are individuals who began working before the reform, whereas "new people" are those who started working after the reform. "Old people" are individuals who retired before the reform. National statistics reveal that the number of universities in China reached 2138 in 2012. Besides, the state intended to launch the old-age pension reform of administrative institutions from October 1, 2014. According to the policy design of "the old way for the old people, middle people follow the transitional approach, and the new way for the new people," college staff who retired before October 1, 2014 will not participate in the pension reform. The school will still be responsible for their pension, and the level of benefits for the old people will remain unchanged. The pension plan for "new people" is calculated separately. Thus, the core issue is the benefits of "middle people."

In 2015, the Ministry of Human Resources and Social Security together with the Ministry of Finance issued a notice on the implementation of the "Decision of the State Council on the Reform of the Old-age Pension System for Staff of Public Institutions" and proposed the 10-year transition plan for "middle 
people."

A unified "middle people" transition method was adopted throughout the country. A 10-year transition period was established for "middle people" who started working before October 1, 2014 and retired after the reform. The new method includes occupational annuity. Comparing the results of the new method with those of the old one, and if the calculation result of the new method is lower than that of the old method, the pension shall be paid according to the standards of the old method. Below is the computation regarding the part that exceeds the benefits according to old rules.

Those who retire in the first year (October 1, 2014 to December 31, 2015) receive $10 \%$ of the excess, those who retire in the second year will receive $20 \%$ (January 1, 2016 to December 31, 2016), and so on. Those who retire at the end of the transition period (January 1, 2024 to September 30, 2024) will receive $100 \%$ of the excess.

New calculation methods will be used after the transition.

Formulas for calculation based on the old rules:

$$
(A \times M+B+C) \times \prod_{n=2015}^{N}\left(1+G_{n-1}\right)
$$

$A$ refers to the basic wage of staff in September 2014.

$B$ is the pension according to the technical title of the staff in September 2014.

$C$ refers to the corresponding increase of retirement benefits as specified in the document.

$M$ is the ratio of working years calculated according to the old method.

$G_{N-1}$ is the wage growth rate determined by factors, such as the increase in wages of employees in the $n-1$ year, $n \in[2015,2024]$, and $G_{2014}=0$.

$N$ is the number of working years during the transition period, $n \in[2015,2024]$.

For retirements from October 1, 2014 to December 31, 2014, the retirement year will be treated as 2015 .

Formulas for calculation based on the new rules = pension + occupational annuity:

Pension $=$ basic pension + transitional pension + individual account pension.

The calculation method is

Basic pension $=$ the average monthly salary of the local employees in the previous year before the retirement $\times(1+$ average contribution wage index $) \div 2 \times$ contribution period (including the deemed contribution period, the same below) $\times 1 \%$

Average employee wages index $=$ (the deemed contribution index $\times$ the deemed contribution period + the actual average contribution index $\times$ the actual contribution period) $\div$ contribution period

Through actuarial calculations, the localities form a list of deemed contribution indices, and the index should correspond to the ranks (technical titles) and working years of the local public institutions.

When the staff member retires, the corresponding contribution index is determined by the index table. 


\section{Actual average contribution index:}

$$
\frac{X_{n}}{C_{n-1}}+\frac{X_{n-1}}{C_{n-2}}+\cdots+\frac{X_{2016}}{C_{2015}}+\frac{X_{2015}}{C_{2014}}+\frac{X_{2014}}{C_{2013}} / N
$$

Transitional pension $=$ the average monthly salary of the local employees in the previous year before the retirement $x$ deemed contribution period $\times$ deemed contribution index $\times$ transition coefficient

The transition coefficient is consistent with the transition coefficient of the basic old-age pension for enterprise employees, and the deemed contribution index is uniformly determined by each province-level region.

Individual account pension $=$ the total accumulated amount of the basic old-age pension personal account when retired $\div$ the number of months to be counted (the number of months to be issued is stipulated by the government)

According to the 10-year transition formula for "middle people" above, several problems still exist.

First, how can the situation wherein benefits of "middle people" are lower than the treatment calculated by the old rules be addressed? In the enterprise old-age pension schedule, numerous "empty accounts" of individuals exist. The reason is that individual account funds have been eroded by pooled social funds. In addition, the social pooling part of China's pension is operated on a pay-as-you-go system. For the 101.03 million retirees who have none or insufficient contributions in 2016, the considerable part of their pension benefits are exactly the pension paid by the in-service employees. Therefore, the phenomenon of "empty accounts" in individual accounts is extremely serious. At present, the contributions of public institution pension are insufficient. If handled improperly, this insufficiency will likely cause serious problems, similar to that of enterprise old-age pension reform. In addition, only a few universities in China have a long history in which age structure is aging, and the burden of old-age care is particularly serious. After the implementation of the old-age pension insurance reform, if the benefits of "middle people" do not decline, and the funds in the overall accounts are insufficient, then individual accounts funds are bound to be eroded, which may trigger the financial risk of "first benefits and then suffering."

Second, how can the deemed contribution indices be set fairly? It is necessary to take regional differences into account while ensuring that the benefits of "middle people" do not decrease. The provinces should have followed the principles mentioned above and issued corresponding deemed contribution indices. However, in fact, they have not issued any policies. Moreover, the internal structure of "middle people" is rather complicated. Some of them have just recently joined the workforce, whereas some are about to retire. Under the circumstances, keeping the benefits of "middle people" uncut may be impossible.

Third, the staff in undergraduate colleges and universities in Guangzhou have been paying personal account funds for 20 years, which is in line with the reform of enterprise old-age pension. Consequently, staff have their own individual accounts while the unit does not pay any contribution. The practice before the 
reform was that the Human Resources and Social Security Bureau liquidated the balance of individual accounts previously paid and return them to the retired staff. Now, the reform has been implemented. For "middle people" who are staff in Guangdong universities and retired after the reform, how to deal with the balance of their individual account that accumulates previously when they retire? Should the Human Resources and Social Security Bureau return the contributions of individual accounts all at once, or should the part that has already been paid considered the accumulated amount of the individual account? Either way can be controversial.

The State Council issued the "Implementation Plan for Enrolling Some State-owned Capital Enrichment Social Security Funds" on November 20, 2017, clearly stating that $10 \%$ of the equity of state-owned capital enterprises will be allocated to the fund for basic old-age pension for enterprise employees so as to bridge the pension gap caused by the deemed contribution years during the transition period. The government should pay enough attention to the great pension gap between colleges and other institutions, which caused by the deemed contribution years of "middle people." In addition, despite numerous colleges and universities in China, only a few have previously participated in the reform of local old-age pension. Unifying actions in reform requires rational arrangements for policies.

Sixth, the value added by occupational annuity in colleges and universities has uncertainties.

Educational units are important parts of public institutions, as their staffs account for more than $50 \%$ of public institutions. The classification reform of public institutions including colleges and universities involves five aspects, namely, personnel employment system, organization establishment, management system, performance salary, and old-age pension. The government should select some institutional investors to manage pensions. For example, the government can opt for banks or trust companies as fund custodians and professional investors as fund investment managers. No matter which agencies are chosen, the most important aim is to obtain sufficient returns through expert financing and make retirees earn better returns. For enterprises affiliated to universities or engaged in production and business activities, they shall be gradually transformed into enterprises in the market and participate in the reform of enterprise old-age pension.

As for the issue of putting enterprise annuities funds into stocks, the government has introduced policies and restricted the proportion of investment. In April 2013, the Notice of the Ministry of Human Resources and Social Security, the China Banking Regulatory Commission, the China Securities Regulatory Commission, and the China Insurance Regulatory Commission jointly issued the "Notice on Expanding the Investment Range of Enterprise Annuity Funds." In addition, the investment ratio of enterprise annuity to investment stocks, stock funds, hybrid funds, investment-linked insurance products, and stock-based pension products shall not exceed $30 \%$ of the net value of invest- 
ment portfolio investment assets. The enterprise annuity investment method applies to the university occupational annuity investment likewise. In contrast with the encouraging attitude toward the enterprise annuity, occupational pension in colleges and universities is more than restrictive. The Ministry of Finance, the Ministry of Human Resources and Social Security, and the State Administration of Taxation jointly issued the notice on issues related to individual income tax of enterprise annuity and occupational annuity (Caishui [2013] No. 103). This notice stipulated that the preferential policy of delayed payment of individual income tax of enterprise annuity and occupational annuity shall be implemented as of January 1, 2014. The Ministry of Finance and the Ministry of Education jointly issued the "Financial System of Colleges and Universities" (Caijiao [2012] No. 488), which stipulates that non-financial allocations of colleges and universities shall be carried over to the next year in accordance with regulations, and employee welfare funds may be withdrawn. These two documents respectively propose the preferential policies and the source of occupational annuities.

The prerequisite for the establishment of professional annuity in colleges and universities is to participate in basic old-age pension and fulfill the contribution obligation as well as having economic affordability and establishing a collective bargaining mechanism. Any establishment of occupational pension scheme needs to be approved by the Human Resources Social Security Department, and the appointed occupational pension trustee. The trustee shall entrust the qualified occupational annuity account manager and the custodian of the investment manager shall be responsible for the operation of the annuity fund and provide the optimal pension security for the staff. In terms of management approaches, college occupational annuities can be managed internally or externally. For example, Huazhong University of Science and Technology owns listed companies and has issued a series of stocks such as Huagong Technology and Huazhong CNC. The staff of Huazhong University of Science and Technology can use the pension to replace Huagong Technology and Huazhong CNC stocks at a lower price, which means that the contributions of pension are the stock of the school-run enterprises. This type of faculty shareholding plan of colleges and universities is the main form of occupational annuity plan. Moreover, the council of occupational annuity allocates assets to individual accounts based on the employee's corresponding salary level or labor contributions and size of responsibility. Simply put, the staff has low-cost share purchases and income rights, but the stocks are not listed for circulation. Employees can only obtain the balances on their individual accounts when they resign or retire. The goal of the plan is to link the economic benefits of listed companies with the annuity of employees to motivate the staff through the market performance of the company's stocks, and to increase the value of old-age pension. For science and engineering colleges known for good efficiency, or school-run companies, the stock incentive plan is advantageous to the value-added occupational annuity.

As far as capital market is concerned, that the pensions of public institutions 
will be directly invested in shares in the near future is widely accepted. However, management groups are inclined to deliberately turn things down. Some experts suggest not to put pension funds into stocks until the stock market crashes. Now, the stock market is not short of money, so investing pension funds is stocks is unnecessary. If a large amount of pension fund is invested, even if it is only $30 \%$, it will inevitably lead to a sharp rise in the stock index. If the management's decision is in line with the expert opinion, the occupational annuity will be likely restricted to the market, and a few of the bull market dividends will be lost.

Seventh, the reform may have an impact on the flow of talents in colleges and universities.

First, the competition of talents in "Double First-Class" universities has become increasingly fierce. Old-age pension plan for public institutions requires provincial-level coordination. For migrants who travel across the same province, their pension relationships are also transferred, but the funds remain unchanged. If talents flow across provinces, either the pension insurance relationship or the storage of basic pension individual amount will be transferred together, and $12 \%$ of the storage of the actual contributions of the floating personnel shall be transferred. If the contribution year is less than one year, the transfer fund shall be calculated according to the actual number of contributions. After the transfer, the contribution period (including the deemed period) along with the personal account storage amount are calculated cumulatively, and both will not be cleared. This method is the same as that of transfer of migrant workers in the enterprise old-age pension reform system, which confronted several obstacles in practice. As no unified national stipulation is laid down for the "mutual recognition of the number of contribution years" and other aspects, if migrant workers travel across the country, the local department usually adopts the "shelved" approach, which results in serious termination of insurance. In the flow of high-end talents in China, the southeastern coastal areas are the main inflow areas, whereas the flow of inland university teachers to developed areas has become mainstream. The flow of the mainland's pooled social funds to developed regions may also have a problem of "mutual cognition of contribution years," which hamper the flow of talents in universities.

Second, staff of colleges and universities will inevitably participate the professional annuity plan, but distinctions between universities cannot be ignored. The State Council documents do not clearly stipulate whether the occupational annuity of personnel will be transferred after the inter-provincial flow of talents or not. If the occupational annuity can be transferred along with it, it may encounter resistance from the mainland universities. If not, the flow of talent will become difficult. In public sector human resource management, annuity is an effective management approach for talent incentives. Therefore, only if colleges and universities in developed areas increase the intensity of talent introduction and compensate for occupational annuity can the problem be solved to a certain 
extent.

Third, the flow of talents between enterprises and universities involves the transfer of old-age pension. In response, the government has issued the "Notice on the Basic Old-age Pension Insurance Relationships of Governments and Institutions and the Transfer and Continuation of Occupational Annuities." However, the actual operation is beset with difficulties. Roughly 10 million staff in colleges, universities, and public hospitals nationwide are permanent as well as millions of unregistered staff included in the government budget. The problem is that, the old-age pension reform program in 2014 did not take into account the pension of unregistered staff. In recent years, high-level construction in colleges and universities across the country has accelerated, and the number of unregistered staff has been expanding rapidly. In January 2016, the Ministry of Human Resources and Social Security revealed that universities and hospitals will not be included in the scope of public institutions, which will reduce the staffing of administrative institutions by approximately $60 \%$. Thus, the promotion of pension insurance of administrative institutions will be facilitated. The traditional mode of contributions according to the number of employees in colleges and universities will be transformed into a more comprehensive and complicated one, and may contribute to a major change in the employment mechanism of colleges and universities. In summary, old-age pension will become a daunting task in the construction of high-level universities.

\section{Acknowledgements}

The research is supported by the key project of the Ministry of Education of China (16JJD840011) and the post-funded projects of the National Social Science Fund (18FGL026).

\section{Conflicts of Interest}

The authors declare no conflicts of interest regarding the publication of this paper.

\section{References}

Miyazaki, \& Koichi (2014). The Effects of the Raising-the-Official-Pension-Age Policy in an Overlapping Generations Economy. Economics Letters, 123, 329-332. https://doi.org/10.1016/j.econlet.2014.03.011

Wang, C.-Q. et al. (2018). A Research on the Impacts of Pension Reform on Finance and Expenditure of Government Departments and Institutions. Insurance Studies, (6).

Wang, L.-J. et al. (2014a). Pension Fairness in China. China Economic Review, 28, 25-36. https://doi.org/10.1016/j.chieco.2013.11.003

Wang, L.-J. et al. (2014b). Pension Financing in China: Is There a Looming Crisis? China Economic Review, 30, 143-154. https://doi.org/10.1016/j.chieco.2014.05.014

Zhao, X.-T., \& Yang, Y.-S. (2017). An Evaluation on China's Basic Pension Adjustment Policy Based on the Perspective of Fairness and Efficiency. Chinese Public Administration. 
Zhu, H.-Y., \& Walker, A. (2018). Pension System Reform in China: Who Gets What Pensions? Social Policy \& Administration, 52, 1410-1424.

https://doi.org/10.1111/spol.12368 